\title{
Insulin receptors in lizard brain and liver: structural and functional studies of $\alpha$ and $\beta$ subunits demonstrate evolutionary conservation
}

\author{
J. Shemer, J.C. Penhos and D. LeRoith \\ Section of Molecular and Cellular Physiology, Diabetes Branch, National Institute of Arthritis, Diabetes, Digestive and Kidney Diseases, \\ Rockville Pike, Bethesda, Maryland, USA
}

\begin{abstract}
Summary. Specific insulin receptors are present in the liver and brain of the lizard Anolis carolinesis. In this study, the specific binding of ${ }^{125} \mathrm{I}$-insulin to the receptors showed time, temperature and $\mathrm{pH}$ dependency. Specific binding to crude membranes prepared from brain was $1-2 \%$ of the total radioactivity added compared to $4-5 \%$ in the crude membranes prepared from liver. Solubilization and wheat germ agglutinin purification of the membranes resulted in an increase in the specific binding (per $\mathrm{mg}$ of protein) between 6 and 32 times for liver membranes and 13-186 for brain membranes. Binding inhibition of tracer insulin by unlabeled porcine insulin was characteristic for insulin receptors with 50\% inhibition for liver crude membranes at $60 \mathrm{ng} / \mathrm{ml}$ of porcine insulin and $0.7 \mathrm{ng} / \mathrm{ml}$ for purified brain insulin receptors. Chicken insulin was 2- to 3-fold more potent and proinsulin about 100 times less potent than porcine insulin. The $\alpha$-subunits of liver and brain had apparent molecular weights on sodium dodecyl sulfate polyacrylamide gel electrophoresis of $135 \mathrm{kDa}$ and
\end{abstract}

$120 \mathrm{kDa}$ respectively. Apparent molecular weights of $\beta$ subunits were $92 \mathrm{kDa}$ for both tissues. Insulin stimulated phosphorylation of the $\beta$ subunit of both brain and liver receptors. Both tissues demonstrated tyrosine-specific phosphorylation, which was stimulated by insulin, of exogenously added artificial substrates. In addition, purified brain insulin receptor preparations contained an endogenous protein with apparent molecular weight of $105 \mathrm{kDa}$, whose phosphorylation was stimulated by insulin $\left(10^{-7} \mathrm{~mol} / 1\right)$. This phosphoprotein was not immunoprecipitated by anti-insulin receptor antibodies. These studies suggest that the structural differences between brain and liver receptors previously demonstrated in the rat are also present in the lizard, which is about $300,000,000$ years older than the mammalian species. Thus, there is strong evolutionary conservation of the brain insulin receptor.

Key words: Insulin receptor, nervous system, phosphorylation, evolution, reptiles.
The insulin receptor is a membrane bound glycoprotein composed of two $\alpha$-subunits and two $\beta$ subunits joined by disulfide bonds [1]. The recent cloning of the insulin receptor gene and the derivation of the amino acid sequence from the gene has suggested that the $\alpha$ subunit is predominantly an extracellular subunit containing most of the glycosylation sites. The $\beta$ subunit contains a transmembrane domain as well as a cytoplasmic domain with the tyrosine phosphorylation site $[2,3]$. Binding of insulin to the insulin receptor occurs primarily through the $\alpha$ subunit, and the $\beta$ subunit is capable of autophosphorylation as well as tyrosine specific phosphorylation of exogenous substrates $[4,5]$, a function which it shares with other growth factors such as epidermal growth factor, insulin-like growth factor I, and platelet derived growth factor [6].

Insulin receptors are found on most tissues in all mammalian and vertebrate species studied [7-17]. Although a specific function for insulin on the nervous system has not been convincingly demonstrated, the wide distribution of the insulin receptor on specific cell types in the nervous system strongly suggests that insulin may play an important role in the physiology of the nervous system [11, 17, 18]. Recently, structural and functional studies of the insulin receptor in the rat brain have suggested that the $\alpha$ subunit of rat brain insulin receptor is smaller than that in non-neural tissues such as liver and adipocytes [19-22]. Despite these structural changes the rat brain insulin receptor is functional, demonstrating phosphorylation of the $\beta$ subunit and tyrosine specific phosphorylation of artificially synthesized exogenous substrates [23]. This difference in structure has been assigned to a variation in the carbohydrate moeities in the rat brain insulin receptor.

To determine whether the difference in brain and non-neural insulin receptors of the rat is species-specific and whether this is evolutionarily well conserved, we have studied Anolis carolinesis (lizard), a representative 
of the reptile family. In this study we demonstrate that the brain insulin receptor of the lizard differs from liver receptors similar to the differences found in the rat. Thus, the $\alpha$ subunit of the lizard brain insulin receptor has a smaller molecular weight than that of the liver receptor. Despite this structural difference, the $\beta$ subunit of both brain and liver receptors demonstrate insulindependent autophosphorylation and tyrosine specific phosphorylation of exogenous substrates.

\section{Materials and methods}

\section{Materials}

${ }^{125} \mathrm{I}$-insulin (specific activity $280-370 \mathrm{mCi} / \mathrm{mg}$ ) and $\left[\gamma_{-}{ }^{32} \mathrm{P}\right] A T P$ (specific activity $2900 \mathrm{Ci} / \mathrm{mol}$ ) were purchased from New England Nuclear (Boston, MA, USA). Porcine insulin was purchased from Elanco (Indianapolis, IN, USA) and biosynthetic human proinsulin (A18-4U6-253) was purchased from Eli Lilly and Co (Indianapolis, IN, USA). Chicken insulin (from Littron Laboratories) was obtained through the Research Resources Program of the National Institute of Arthritis, Diabetes, Digestive and Kidney Diseases, National Institutes of Health (Bethesda, MD, USA). Wheat germ agglutinin (WGA) coupled to agarose was purchased from Miles-Yeda Ltd. (Rehovot, Israel). Phenylmethylsulfonyl Fluoride (PMSF), Bacitracin, Leupeptin and Aprotinin were purchased from Sigma Chemical (St. Louis, MO, USA). Bovine serum albumin (insulin-free) was purchased from Armour Pharmaceutical (Kankakee, IL, USA). Guinea pig anti-insulin antiserum (batch 625) was purchased from the Department of Pharmacology, Indiana University (Indianapolis, IN, USA). Patient sera containing anti-insulin receptor antibodies (designated $B_{8}, B_{10}$ ) and anti-pp120 antibodies were generously donated by Dr. Simeon Taylor, National Institutes of Health, (Bethesda, MD, USA). CTP, ATP, N-acetyl-D-glucosamine, neuraminidase (from Clostridium perfringens, type $\mathrm{N} 2133$ ), and artificial tyrosine containing substrates, i. e. poly (Glu, Tyr), 4:1, poly (Glu, Tyr), 1:1, poly (Glu, Ala, Tyr), 6:3:1, poly (Glu, Ala, Tyr), 1:1:1, poly (Glu, Ala, Tyr), $6: 3: 1$ and poly (Ala, Glu, Lys, Tyr), 6:2:5:1 were purchased from Sigma Chemical (St.Louis, MO, USA). All reagents for electrophoresis were obtained from Bio-Rad Laboratories (Richmond, CA, USA). Protein A (pansorbin) was purchased from Calbiochem Behring ( $\mathrm{La}$ Jolla, CA, USA).

\section{Preparation of crude membrane}

Male adult lizards, Anolis carolinesis (1.5-4.5 g), were purchased from Carolina Biological Supply Co. (Burlington, NC, USA). The animals were decapitated; the brains and livers were immersed in icecold homogenization buffer $(15 \mathrm{v} / \mathrm{w})$ containing $1 \mathrm{mmol} / 1 \mathrm{NaHCO}_{3}$, $2 \mathrm{mmol} / 1 \mathrm{PMSF}, 10 \mu \mathrm{g} / \mathrm{ml}$ Leupeptin and Aprotinin at a final concentration of 1 trypsin inhibitory unit per ml. Tissues were homogenized in a glass/glass homogenizer (Ten Broek Model, Corning Glass Works, Corning, NY, USA) using 20 strokes of the pestle. The homogenate was centrifuged at $600 \mathrm{~g}$ for $10 \mathrm{~min}$ at $4^{\circ} \mathrm{C}$. The resultant supernatant was centrifuged at $20,000 \mathrm{~g}$ for $30 \mathrm{~min}$ at $4^{\circ} \mathrm{C}$ and the supernatant was discarded. The pellet was then resuspended in KRP assay buffer (Krebs Ringer phosphate buffer, $\mathrm{Ca}^{++}$free, containing $150 \mathrm{mmol} / 1 \mathrm{NaCl}, 5 \mathrm{mmol} / 1 \mathrm{KCl}, 1.2 \mathrm{mmol} / 1 \mathrm{KH}_{2} \mathrm{PO}_{4}, 16 \mathrm{mmol} / 1$ potassium phosphate buffer, $16 \mathrm{mmol} / 1 \mathrm{Na}_{2} \mathrm{HPO}_{4}$ and $1.2 \mathrm{mmol} / 1$ $\mathrm{MgSO}_{4} \cdot 7 \mathrm{H}_{2} \mathrm{O}$ ) to a protein concentration of approximately $10 \mathrm{mg} / \mathrm{ml}$ as determined by the Lowry method [24] and stored at $-70^{\circ} \mathrm{C}$ in aliquots for up to 6 months before use.

\section{Insulin binding studies}

Binding assays were performed as previously described by Havrankova et al. [11]. Time dependency, optimal $\mathrm{pH}$ and protein concentration were determined. For competition binding assays, the final membrane protein concentration was $700 \mu \mathrm{g} / \mathrm{ml}$ for liver and brain tissues. Total reaction volume of the assay was $150 \mu \mathrm{KRP}$ buffer consisting of ${ }^{125} \mathrm{I}$ insulin $(0.3 \mathrm{ng} / \mathrm{ml}), 1 \%$ bovine serum albumin and $1 \mathrm{mg} / \mathrm{ml} \mathrm{Bacitrac-}$ in, with or without unlabeled pork insulin (final concentration $0-10^{5} \mathrm{ng} / \mathrm{ml}$ ), and included $50 \mu \mathrm{l}$ of membranes. Specificity studies included the use of proinsulin and chicken insulin. Radioactivity bound to the membranes in the presence of $10 \mu \mathrm{g} / \mathrm{ml}$ of unlabeled pork insulin was designated "nonspecific binding" and was subtracted from the total binding to obtain "specific binding". The assays were performed in microfuge tubes at $4^{\circ} \mathrm{C}$ for $18 \mathrm{~h}$. After incubation, the tubes were centrifuged for $3 \mathrm{~min}$; the supernatants were aspirated and discarded. The pellets were washed with KRP buffer containing $0.5 \mathrm{~mol} / 1$ sucrose; the microfuges were spun again for $3 \mathrm{~min}$, the supernatants were aspirated and the tips of the microfuge tubes containing the pellets were counted in a $\gamma$ counter. Degradation of ${ }^{125} \mathrm{I}$-insulin was determined by its solubility in $5 \%$ trichloroacetic acid and was found to be negligible $\left(<5 \%\right.$ after $18 \mathrm{~h}$ at $\left.4{ }^{\circ} \mathrm{C}\right)$.

\section{Solubilization of the membrane and wheat-germ agglutinin chromatography}

Both liver and brain membranes were solubilized as previously described by Hedo et al. [25]. Briefly, the pellets of the crude membranes were resuspended in $50 \mathrm{mmol} / 1$ Hepes buffer $(\mathrm{pH} 7.8)$ with $1 \%$ Triton $\mathrm{X}-100$ and $2 \mathrm{mmol} / 1 \mathrm{PMSF}$. The homogenate was centrifuged at $40,000 \mathrm{~g}$ for $45 \mathrm{~min}$ at $4^{\circ} \mathrm{C}$ and the supernatant with the solubilized receptors was saved. $30-240 \mathrm{mg}$ solubilized membrane protein from brain and $30 \mathrm{mg}$ of liver were affinity purified in a volume of $7 \mathrm{ml}$ buffer over a 2-ml WGA column. The columns were eluted as 1-ml fractions with $7-20 \mathrm{ml}$ of the same washing buffer containing $0.3 \mathrm{~mol} / 1 \mathrm{~N}$ acetyl-D-glucosamine. The protein concentration [26], as well as tracer binding (see below), were determined in all fractions. The fractions with the highest protein concentration and the highest specific binding $(10-20 \%)$ were stored at $-70^{\circ} \mathrm{C}$ for up to 6 months before use.

\section{Solubilized receptor binding assays}

Binding assays were performed as previously described by Harrison and Itin [27] with minor modifications. Briefly, the total reaction volume of the assay was $200 \mu \mathrm{l}$, and consisted of $50 \mu \mathrm{l}$ of the assay buffer at $\mathrm{pH} 7.8(50 \mathrm{mmol} / 1 \mathrm{Hepes}, 150 \mathrm{mmol} / 1 \mathrm{NaCl}$ and $0.1 \% \mathrm{BSA}), 125 \mu$ of ${ }^{125} \mathrm{I}$-insulin diluted in the assay buffer (final concentration $0.3 \mathrm{ng} /$ ml) with $1 \mathrm{mg} / \mathrm{ml}$ Bacitracin, $0.1 \%$ BSA and $25 \mu \mathrm{l}$ of the solubilized and WGA purified membranes $(\sim 160 \mu \mathrm{g} / \mathrm{ml})$ in $0.1 \%$ Triton X-100. The final membrane protein concentration in the incubation was $20 \mu \mathrm{g} / \mathrm{ml}$, i. e. $4 \mu \mathrm{g}$ of membrane protein per assay tube. The assay was incubated for $4 \mathrm{~h}$ (as indicated by the time course, Fig.3) with and without pork insulin, proinsulin and chicken insulin (final concentration $0-10^{5} \mathrm{ng} / \mathrm{ml}$ ), at $22^{\circ}-24^{\circ} \mathrm{C}$. To terminate the reaction, $100 \mu \mathrm{l}$ of $0.3 \%$ bovine $\gamma$-globulin and $300 \mu 1$ of $25 \%$ polyethylene glycol was added and the tubes immediately chilled. Precipitates were collected by centrifugation at $2500 \mathrm{~g}$ for $15 \mathrm{~min}$ at $4{ }^{\circ} \mathrm{C}$, and washed once with $300 \mu \mathrm{l}$ of $12.5 \%$ polyethylene glycol. The supernatants were aspirated and discarded and the radioactivity in the tubes counted in the $\gamma$ counter. Radioactivity bound to the membranes in the presence of $10 \mu \mathrm{g} / \mathrm{ml}$ of unlabeled pork insulin was designated "non-specific binding" and subtracted from the total binding to obtain "specific binding". Degradation of ${ }^{125} \mathrm{I}$-insulin was determined by precipitation with $5 \%$ trichloroacetic acid and was found to be negligible $(<5 \%$ after $4 \mathrm{~h}$ at $22^{\circ}-24^{\circ} \mathrm{C}$ ).

\section{Crosslinking of ${ }^{125}$ I-insulin to insulin receptors}

Crosslinking of ${ }^{125} \mathrm{I}$-insulin to insulin receptors was performed as described previously by Taylor et al. [28] with minor modifications. Lizard liver or brain membranes [final concentration 10 and $20 \mathrm{mg} / \mathrm{ml} \mathrm{re-}$ 
Table 1. Insulin-stimulated phosphorylation of artificial substrates by brain and liver insulin receptors

\begin{tabular}{|c|c|c|c|c|c|c|}
\hline \multirow[t]{3}{*}{ Substrate } & \multicolumn{3}{|c|}{ Brain } & \multicolumn{3}{|c|}{ Liver } \\
\hline & \multicolumn{2}{|c|}{$\begin{array}{l}{ }^{32} \mathrm{P} \text { incorporated } \\
\text { (arbitrary units) } \\
\text { Insulin }\end{array}$} & \multirow[t]{2}{*}{$\begin{array}{l}\text {-fold } \\
\text { stimulation }\end{array}$} & \multicolumn{2}{|c|}{$\begin{array}{l}{ }^{32} \mathrm{P} \text { incorporated } \\
\text { (arbitrary units) } \\
\text { Insulin }\end{array}$} & \multirow[t]{2}{*}{$\begin{array}{l}\text { fold } \\
\text { stimulation }\end{array}$} \\
\hline & 0 & $10^{-7} \mathrm{~mol} / 1$ & & 0 & $10^{-7} \mathrm{~mol} / 1$ & \\
\hline Poly(Glu, Tyr), 4:1 & 50 & 320 & 6.4 & 200 & 300 & 1.5 \\
\hline Poly(Glu, Tyr), 1:1 & 2 & 2 & - & 2 & 2 & - \\
\hline Poly(Glu, Ala, Tyr), 6:3:1 & 45 & 125 & 2.7 & 90 & 115 & 1.3 \\
\hline Poly(Glu, Ala, Tyr), $1: 1: 1$ & 2 & 2 & - & 2 & 2 & - \\
\hline Poly(Ala, Glu, Lys, Tyr), $6: 2: 5: 1$ & 37 & 82 & 2.2 & 94 & 125 & 1.3 \\
\hline
\end{tabular}

Brain and liver insulin receptor preparations containing 4-10 $\mu \mathrm{g}$ of protein were incubated in the presence or absence of $10^{-7} \mathrm{~mol} / 1 \mathrm{porcine}$ insulin at $22^{\circ}-24^{\circ} \mathrm{C}$ for $30 \mathrm{~min}$. Phosphorylation was performed for $30 \mathrm{~min}$. In repeat experiments values for -fold stimulation using poly(Glu, Tyr) 4:1 gave results of 5-to 10 -fold for brain and 1.5-2.0 for liver. Using similar conditions for rat tissues, -fold stimulation was 1.7 and 5.0 for brain and liver respectively

spectively] were added to ${ }^{125} \mathrm{I}$-insulin [final concentration $10 \mathrm{ng} / \mathrm{ml}$ ] and incubated overnight at $4^{\circ} \mathrm{C}$. Sprague-Dawley rat liver and brain membranes (final concentration $5 \mathrm{mg} / \mathrm{ml}$ ) were also studied for comparison. Incubations were terminated by centrifugation at $12,000 \mathrm{~g}$ for $30 \mathrm{~min}$ at $4{ }^{\circ} \mathrm{C}$. The pellets were resuspended in and washed twice with BSA-free KRP pH 7.8. Crosslinking of receptor was performed in KRP $\mathrm{pH} 7.8$ in the presence of $0.1 \mathrm{mmol} / 1$ disuccinimidyl suberate (DSS) for $30 \mathrm{~min}$ on ice. The crosslinking was terminated by the addition of $100 \mathrm{mmol} / 1$ Tris with $10 \mathrm{mmol} / 1 \mathrm{EDTA} \mathrm{pH} 7.4$ and centrifugation at $12,000 \mathrm{~g}$ for $10 \mathrm{~min}$ at $4^{\circ} \mathrm{C}$. Supernatants were aspirated and pellets were resuspended in $50 \mathrm{mmol} / 1$ Hepes $\mathrm{pH} 7.8$. Solubilization of membranes was performed in $1 \%$ Triton $X-100$ and $2 \mathrm{mmol} / 1$ PMSF for $18 \mathrm{~h}$ at $4^{\circ} \mathrm{C}$. The solubilized membranes were ultracentrifuged at $45,000 \mathrm{~g}$ for $45 \mathrm{~min}$ at $4^{\circ} \mathrm{C}$ and the supernatants collected. Immunoprecipitation was carried out by adding $10 \mu \mathrm{l}$ of guinea pig anti-insulin antiserum (final dilution $1: 100$ ) for $18 \mathrm{~h}$ at $4^{\circ} \mathrm{C}$. The immune complexes that bound to Pansorbin were sedimented by centrifugation at $12,000 \mathrm{~g}$ for $5 \mathrm{~min}$. The pellets were washed twice with $50 \mathrm{mmol} / \mathrm{l}$ Hepes buffer $\mathrm{pH} 7.8$ containing $0.1 \%$ Triton X-100. After the addition of $110 \mu \mathrm{l}$ sodium dodecyl sulphate polyacrylamide gel electrophoresis (SDS-PAGE) sample buffer the tubes were vortexed and heated at $95^{\circ} \mathrm{C}$ for $10 \mathrm{~min}$. The Pansorbin was sedimentated by centrifugation, and $50 \mu \mathrm{l}$ of the supernatant containing the crosslinked receptors were subjected to SDS-PAGE. Autoradiography of the dried slab gel was carried out for 3 days.

\section{Neuraminidase digestion of crosslinked receptor}

Either liver or brain receptors were crosslinked to ${ }^{125} \mathrm{I}$-insulin as described above. Prior to solubilization pellets were resuspended in $1 \mathrm{ml}$ of a solution of $5 \mathrm{mmol} / \mathrm{1} 2(\mathrm{~N}$-morpholino) ethanesulfonic acid (MES) and $1 \mathrm{mmol} / 1 \mathrm{CaCl}_{2}, \mathrm{pH} 6$, in the presence or absence of $2.5 \mathrm{U}$ of neuraminidase (type VIII) from Clostridium perfringens and incu-

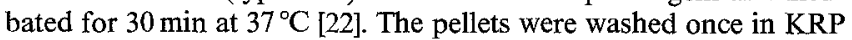
$\mathrm{pH} 7.8$, and solubilized, immunoprecipitated and subjected to SDSPAGE as described above.

\section{Phosphorylation of artificial substrates}

Phosphorylation of artificial substrates by WGA purified receptors was performed as described by Rees-Jones et al. [23]. Briefly, $40 \mu 1$ of WGA purified receptors containing 4-10 $\mu \mathrm{g}$ of protein were incubated $\left(30 \mathrm{~min}\right.$ at $\left.22^{\circ} \mathrm{C}-24^{\circ} \mathrm{C}\right)$ in total volume of $140 \mu \mathrm{l} \mathrm{buffer}(60 \mathrm{mmol} / 1$ Hepes, $50 \mathrm{mmol} / 1 \mathrm{NaCl}, 0.03 \%$ Triton X-100, 0.014\% BSA pH 7.6) and $400 \mu \mathrm{g}$ of various artificial substrates (see Table 1) in the presence or absence of various concentrations of insulin and proinsulin $\left(10^{-9}\right.$ to $10^{-6} \mathrm{~mol} / \mathrm{l}$ ). Phosphorylation was initiated by addition of reaction mix to yield a final concentration of $50 \mu \mathrm{mol} / 1\left(\gamma^{32} \mathrm{P}\right] \mathrm{ATP}$ (specific activity $\sim 3 \mu \mathrm{Ci} / \mathrm{nM}), 1 \mathrm{mmol} / 1 \mathrm{CTP}$ and $20 \mathrm{mmol} / 1 \mathrm{MgCl}_{2}$. After 5 , 15 and 30 min at $20^{\circ}-24^{\circ} \mathrm{C}, 75-\mu$ samples were spotted on squares of Whatmann $3 \mathrm{MM}$ filter paper and $30 \mathrm{~s}$ later were placed in $10 \%$ trichloroacetic acid solution, $10 \mathrm{mmol} / 1 \mathrm{Na}$ pyrophosphate, then washed extensively. Filter papers were dried and ${ }^{32} \mathrm{P}$ incorporation was determined by counting in a liquid scintilation counter.

\section{Insulin receptor autophosphorylation}

Insulin receptor autophosphorylation and immunoprecipitation of the phosphorylated receptors were performed as previously described $[5,29]$. Forty microliters WGA-purified receptor preparation were incubated $\left(30 \mathrm{~min}\right.$ at $24^{\circ} \mathrm{C}$ ) in a total volume of $140 \mu \mathrm{l}$ of buffer $(60 \mathrm{mmol} / 1$ Hepes, $50 \mathrm{mmol} / 1 \mathrm{NaCl}, 0.03 \%$ Triton X-100, $0.014 \%$ BSA, pH 7.6) in the presence or absence of $10^{-7} \mathrm{~mol} / 1$ insulin. Phosphorylation was initiated by adding $40 \mu 1$ of reaction mix to yield a final concentration of $50 \mu \mathrm{mol} / 1\left[\gamma^{32} \mathrm{P}\right] \mathrm{ATP}$ (specific activity $\sim 3 \mu \mathrm{Ci} /$ nmol), $1 \mathrm{mmol} / 1 \mathrm{CTP}, 3 \mathrm{mmol} / 1$ manganese acetate $\mathrm{pH}$ 7.6. After $5 \mathrm{~min}$ at $22^{\circ} \mathrm{C}-24^{\circ} \mathrm{C}$ the reaction was terminated by adding $50 \mu \mathrm{mol} / 1$ of 2.5 -fold concentrated SDS-PAGE sample buffer to each $75 \mathrm{ul}$ of assay samples. The samples were heated for $10 \mathrm{~min}$ at $95^{\circ} \mathrm{C}$ and analyzed by SDS-PAGE and autoradiography.

Immunoprecipitation of the phosphorylated receptors was performed by increasing the volume of the phosphorylation assay mixture 2-fold, decreasing $\left[\gamma-{ }^{32} \mathrm{P}\right] \mathrm{ATP}$ to $5 \mu \mathrm{mol} / 1$ final concentration (specific activity $\sim 50 \mu \mathrm{Ci} / \mathrm{nmol}$ ). Termination of phosphorylation was achieved by adding one-third volume of "stopping solution" containing Triton X-100 (0.2\% v/v), EDTA $(10 \mathrm{mmol} / 1)$, NaF $(0.1 \mathrm{~mol} / \mathrm{l})$, sodium pyrophosphate $(20 \mathrm{mmol} / \mathrm{l})$, sodium phosphate $(20 \mathrm{mmol} / \mathrm{l})$, ATP $(20 \mathrm{mmol} / \mathrm{l})$, Tris base $(0.25 \mathrm{~mol} / \mathrm{l}), \operatorname{SDS}(5 \% \mathrm{v} / \mathrm{v})$, glycerol $(25 \%$ $\mathrm{v} / \mathrm{v}), 2$-mercaptoethanol $(1.82 \mathrm{~mol} / \mathrm{l})$ and bromphenol blue $(0.02 \%$ $\mathrm{v} / \mathrm{v}$ ), $\mathrm{pH}$ 7.6. Antiserum B-8 and B-10 (containing anti-insulin receptor antibodies), rabbit control serum at 1:100 dilution, and anti pp 120 antiserum at 1:40 dilution were then added. The washed immunoprecipitates were boiled in $60 \mu \mathrm{l}$ of SDS-PAGE sample buffer and analysed by SDS-PAGE and autoradiography.

\section{Results}

\section{Insulin binding to liver membranes}

The specific binding of ${ }^{125}$ I-insulin to liver crude membrane was 4 to $5 \%$ of the total radioactivity added using $700 / \mu \mathrm{g}$ membrane protein $/ \mathrm{ml}$ as final concentration and was dependent on time, temperature (Fig.1), pH, and protein concentration (data not shown). Maximal 


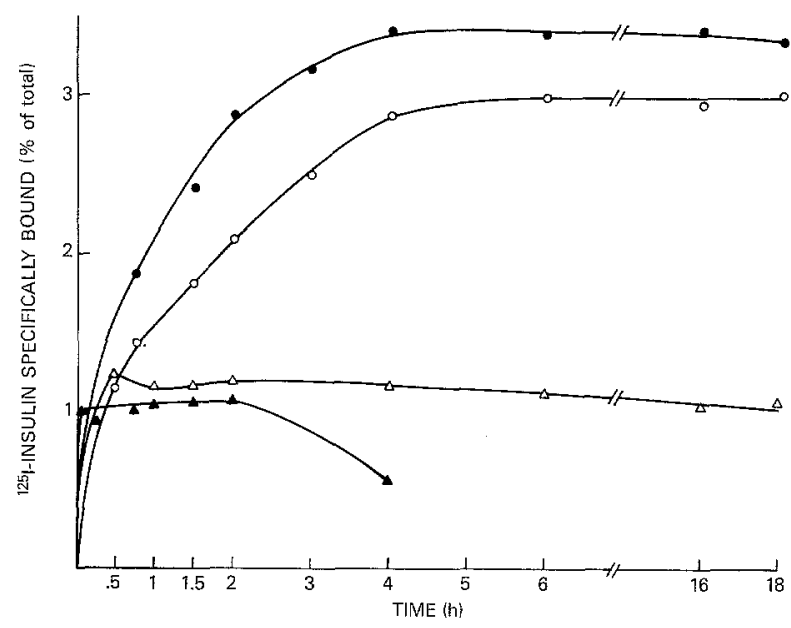

Fig. 1. Time course of association of ${ }^{125} \mathrm{I}$-insulin with lizard liver crude membranes. Membranes were prepared from lizard liver homogenates using $1 \mathrm{mmol} / 1 \mathrm{NaHCO}_{3}$ and protease inhibitors, and were incubated at the various temperatures in KRP buffer ( $\mathrm{pH} 7.8$ ) at a final protein concentration of $700 \mu \mathrm{g} / \mathrm{ml}$. At the indicated time, the reaction was stopped by centrifugation of the tubes for $3 \mathrm{~min}$. The ${ }^{125} \mathrm{I}$ insulin bound to the membranes in the presence of $10 \mu \mathrm{g} / \mathrm{ml}$ unlabeled insulin was considered non-specific and was subtracted from the total binding to give specific insulin binding. Specific binding is expressed as percent of total counts added using $700 \mu \mathrm{g}$ membrane protein $/ \mathrm{ml}$ (final concentration). $4^{\circ} \mathrm{C}(\bullet), 15^{\circ} \mathrm{C}(\mathrm{O}), 22^{\circ} \mathrm{C}(\Delta)$ and $37^{\circ} \mathrm{C}$ (A). Non-specific binding was $25 \%$ of the total binding at $4^{\circ} \mathrm{C}$, $44 \%$ at $15^{\circ} \mathrm{C}, 83 \%$ at $22^{\circ} \mathrm{C}$ and nearly $100 \%$ at $37^{\circ} \mathrm{C}$ at $4 \mathrm{~h}$

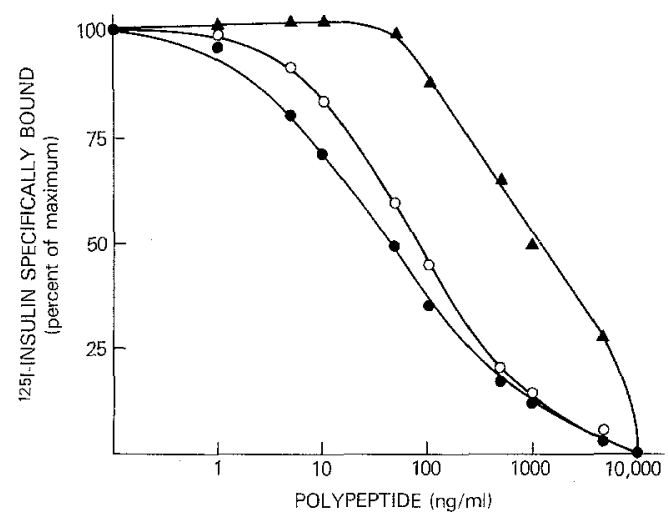

Fig. 2. Competition of ${ }^{125} \mathrm{I}$-insulin binding to lizard liver crude membranes by insulin analogs. Crude membranes were incubated at $4{ }^{\circ} \mathrm{C}$ for $18 \mathrm{~h}$ at a final protein concentration of $700 \mu \mathrm{g} / \mathrm{ml}$ in $\mathrm{KRP}$ buffer ( $\mathrm{pH} 7.8)$ with ${ }^{125} \mathrm{I}$-insulin $(0.3 \mathrm{ng} / \mathrm{ml})$ together with various concentrations $(0-10 \mu \mathrm{g} / \mathrm{ml})$ of porcine insulin $(O)$ proinsulin $(\Delta)$ and chicken insulin (-) from 0 to $10 \mu \mathrm{g} / \mathrm{ml}$. The incubation was stopped by centrifugation of the tubes at $4{ }^{\circ} \mathrm{C}$ for $3 \mathrm{~min}$ and specific binding determined. Fifty percent inhibition of binding was achieved in the presence of $60 \mathrm{ng} / \mathrm{ml}$ of porcine insulin. The relative potencies were chicken insulin $(\bullet)>$ porcine insulin $(O)>$ proinsulin $(\Delta)$

specific binding was achieved at $4^{\circ} \mathrm{C}$ after $4-18 \mathrm{~h}$, and the optimal $\mathrm{pH}$ was 7.8 . The optimal final protein concentration was 0.5 to $0.85 \mathrm{mg} / \mathrm{ml}$. Binding inhibition of ${ }^{125} \mathrm{I}$-insulin by unlabeled porcine insulin was typical for insulin receptors (Fig. 2), with 50\% inhibition at $60 \mathrm{ng} /$

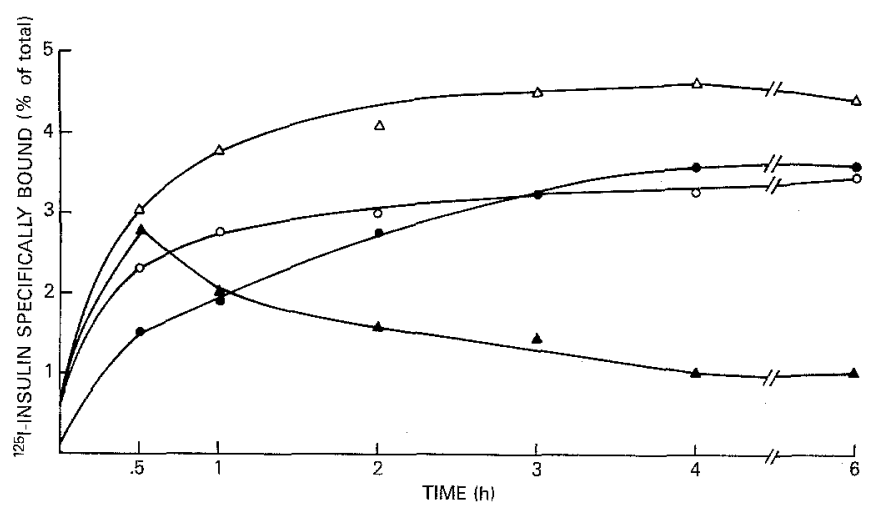

Fig. 3. Time course of association of ${ }^{125} \mathrm{I}$-insulin binding with WGA purified lizard brain insulin receptor. WGA purified receptors were incubated at the indicated temperatures in Hepes buffer $(\mathrm{pH} 7.8)$ at a final protein concentration of $20 \mu \mathrm{g} / \mathrm{ml}$ with ${ }^{125} \mathrm{I}$-insulin in the presence or absence of $10 \mu \mathrm{g} / \mathrm{ml}$ of pork insulin. At various time intervals the reaction was stopped by precipitation with bovine- $\gamma$ globulin and polyethylene glycol and specific insulin binding determined. Specific binding is expressed as percent of total counts added using $4 \mu \mathrm{g} \mathrm{mem}$ brane protein $(20 \mu \mathrm{g} / \mathrm{ml})$ per assay tube $4^{\circ} \mathrm{C}(\bullet), 15^{\circ} \mathrm{C}(\mathrm{O}), 22^{\circ} \mathrm{C}$ $(\triangle)$, and $37^{\circ} \mathrm{C}(\Delta)$. Non-specific binding was $48 \%$ of total binding at $37^{\circ} \mathrm{C}, 11 \%$ at $22^{\circ} \mathrm{C}, 16 \%$ at $15^{\circ} \mathrm{C}$ and $14 \%$ after $4 \mathrm{~h}$ at $4^{\circ} \mathrm{C}$. Maximal specific binding was achieved at $22^{\circ} \mathrm{C}$ after $4 \mathrm{~h}$

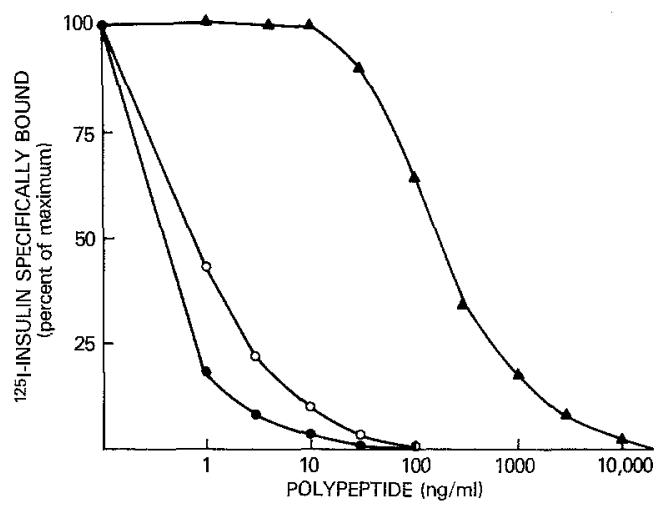

Fig.4. Competition of ${ }^{125} \mathrm{I}$-insulin binding by insulin analogs to solubilized and WGA purified insulin receptor from lizard brain. ${ }^{125} \mathrm{I}$-insulin $(0.3 \mathrm{ng} / \mathrm{ml})$ was incubated at $22^{\circ} \mathrm{C}$ in $200 \mu 1$ Hepes buffer $(50 \mathrm{mmol} / \mathrm{l}) \mathrm{pH} 7.8$ containing $0.15 \mathrm{~mol} / 1 \mathrm{NaCl} 0.1 \% \mathrm{BSA}$ and $1 \mathrm{mg} /$ $\mathrm{ml}$ Bacitracin with solubilized and partially purified brain receptor in a final protein concentration of $20 \mu \mathrm{g} / \mathrm{ml}$. Porcine insulin (O), chicken insulin ( $\bullet$ ) and proinsulin $(\Delta)$ were used at various concentrations from $0-10 \mu \mathrm{g} / \mathrm{ml}$. The incubation was stopped by adding $100 \mu \mathrm{l}$ of $0.3 \%$ bovine $\gamma$-globulin and $300 \mu$ of $25 \%$ polyethylene glycol. After 2 washes the tubes with the precipitate were counted in a $\gamma$ counter and the specific binding determined. Fifty percent inhibition binding was achieved with $0.7 \mathrm{ng} / \mathrm{ml}$ of porcine insulin. The relative potencies were chicken insulin $(\mathbf{O})>$ porcine insulin $(O)>$ proinsulin $(\Delta)$

$\mathrm{ml}$. The liver receptors displayed the specificity characteristic of insulin receptors with the affinity for chicken insulin $>$ porcine $>$ proinsulin. Using the same techniques, the specific binding of ${ }^{125} \mathrm{I}$-insulin to rat liver membranes was $7-8 \%$ of the total radioactivity added. 


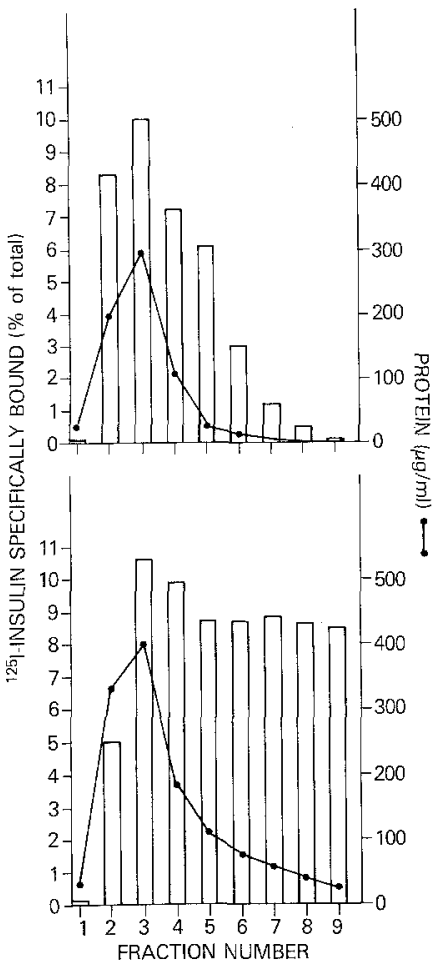

Fig.5. Elution profile of lizard liver and brain insulin receptors from WGA columns. Separate WGA columns $(2 \mathrm{ml}$ of settled gel) were loaded with $7 \mathrm{ml}$ of solubilized liver membranes containing $30 \mathrm{mg}$ of protein (upper panel) and $21 \mathrm{ml}$ of solubilized brain membranes containing $90 \mathrm{mg}$ of protein (lower panel). The insulin receptors were eluted with linear gradients $(9 \mathrm{ml})$ of $\mathrm{N}$-acetyl-D-glucosamine as $1 \mathrm{ml}$ fractions. The protein concentration was determined using fluorescamine [26] and the ${ }^{125}$ I-insulin specifically bound calculated as a percentage of the total counts added. The lizard brain insulin receptors demonstrated an unusual elution profile (lower panel). The specific binding of ${ }^{125} \mathrm{I}$-insulin remained high $(\sim 9 \%)$ despite the fall of protein concentration from $500 \mu \mathrm{g} / \mathrm{ml}$ (fraction 2) to $25 \mu \mathrm{g} / \mathrm{ml}$ (fraction 9). A similar profile for brain insulin receptors was obtained after application of $7 \mathrm{ml}$ of solubilized membranes containing $30 \mathrm{mg}$ of protein

\section{Insulin binding to brain membranes}

Maximal specific binding of ${ }^{125} \mathrm{I}$-insulin to brain crude membranes was $1.2 \%$ of total radioactivity added using $700-\mu \mathrm{g}$ membrane protein protein $/ \mathrm{ml}$ as final concentrations by $18 \mathrm{~h}$ at $4{ }^{\circ} \mathrm{C}, \mathrm{pH} 7.8$ with $50 \%$ inhibition at $4.0 \mathrm{ng} / \mathrm{ml}$ (data not shown). The specific binding was also time, $\mathrm{pH}$, temperature and protein concentration dependent. However, due to low specific binding of brain crude membranes, detailed data for these parameters were studied following WGA purification (see below). Specific binding to rat brain membranes was $5-6 \%$.

\section{Insulin binding to solubilized and wheat germ agglutinin purified brain receptors}

Following WGA purification of brain membranes (see below), specific binding of ${ }^{125} \mathrm{I}$-insulin was time and temperature dependent (Fig.3). The solubilized and WGA-purified brain receptors exhibited 50\% inhibition

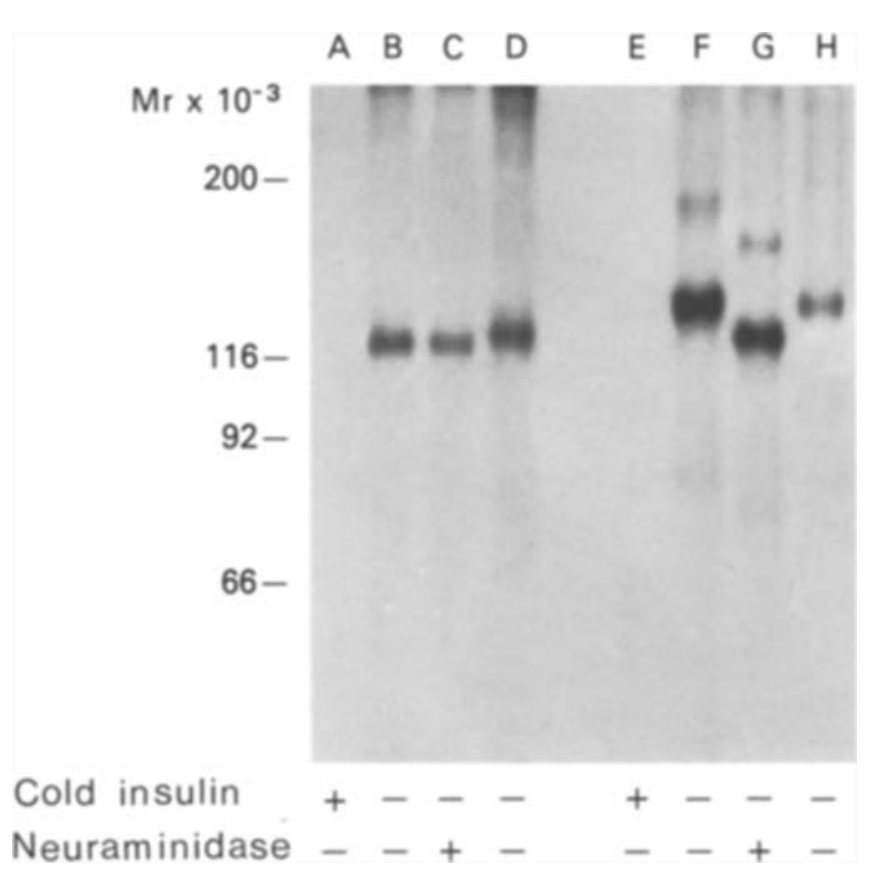

Fig. 6. SDS polyacrylamide gel electrophoresis of ${ }^{125} \mathrm{I}$-insulin crosslinked to liver and brain insulin receptors and the effect of neuraminidase. Lizard brain and liver insulin receptors were crosslinked, immunoprecipitated and treated with neuraminidase. Sprague-Dawley rat brain and liver membranes were also studied for comparison. Lane A-brain receptors, incubated with excess of unlabeled insulin, lane Bcrosslinked lizard brain receptors, lane C-crosslinked lizard brain receptors after neuraminidase digestion. Lane E-lizard liver receptors incubated with excess of unlabeled insulin, lane F-crosslinked lizard liver receptors, lane G-lizard liver receptors after neuraminidase digestion. The apparent molecular weight of the $\alpha$ subunit of the lizard liver receptor is $135 \mathrm{kDa}$ similar to rat liver (lane $\mathrm{H}$ ) and decreased to $120 \mathrm{kDa}$ after neuraminidase digestion. The apparent molecular weight of the lizard brain subunit is $120 \mathrm{kDa}$, similar to rat brain (lane D) and is not affected by neuraminidase digestion. The exact nature of the higher molecular weight bands present in lanes $F$ and $G$ is not known. They may represent partial degradation of the insulin receptor oligomer, since excess cold insulin displaces the label and neuraminidase affects the molecular weight to a similar degree when compared to the $\alpha$-subunit

of ${ }^{125} \mathrm{I}$-insulin in the presence of $0.7 \mathrm{ng} / \mathrm{ml}$ unlabeled pork insulin, and displayed the specificity characteristic of insulin receptors with the affinity for chicken insulin $>$ porcine insulin $>$ proinsulin (Fig. 4).

\section{Wheat germ agglutinin chromatography of the solubilized liver and brain membranes}

WGA chromatography of the solubilized liver and brain membranes in 1\% Triton X-100 resulted in an increase in total specific binding per $\mathrm{mg}$ protein. The -fold increase was 6 to 32 times for liver membranes and 13 to 186 times for the brain membranes (depending on the fraction number, Fig.5). The elution profile of the insulin receptor from WGA columns was different in the two tissues (Fig. 5). The specific binding of ${ }^{125}$ I-insulin 


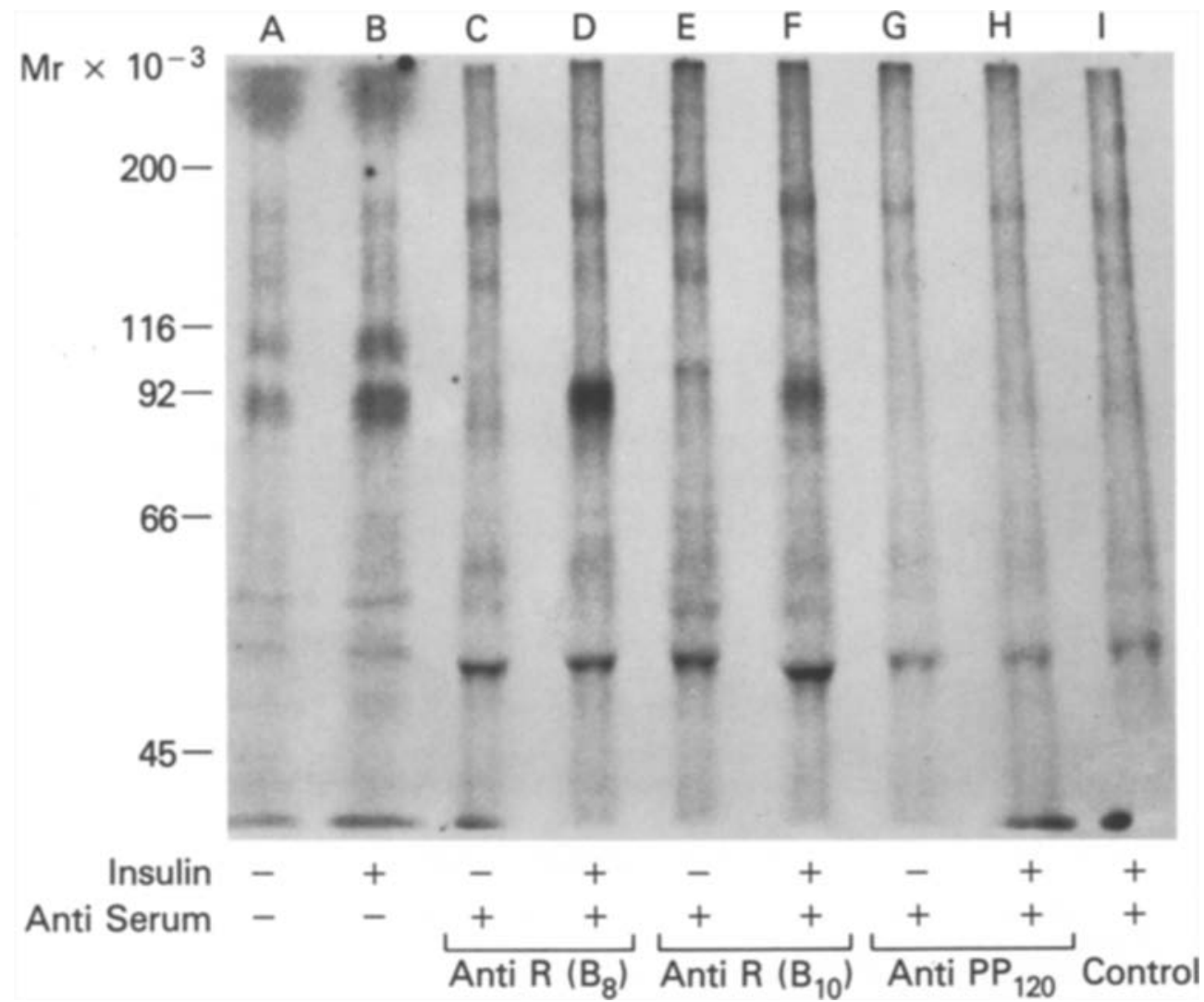

Fig. 7. Insulin-stimulated phosphorylation of brain insulin receptor. WGA purified insulin receptors prepared from lizard brain were incubated $\left(30 \mathrm{~min}, 22^{\circ}-24^{\circ} \mathrm{C}\right)$ in the absence (line A) and presence (lane B) of $10^{-7} \mathrm{~mol} / 1$ insulin. The preparations were phosphorylated with $\left[\gamma^{32} \mathrm{P}\right] \mathrm{ATP}\left(5 \min 22^{\circ}-24^{\circ} \mathrm{C}\right)$. In addition to the insulin stimulated phosphorylation of the $\beta$ subunit $(92 \mathrm{kDa})$, another phosphoprotein (105 kDa) was stimulated. The phosphorylated preparations were immunoprecipitated with anti-receptor antibodies- $\mathrm{B}_{8}$ (lanes $\mathrm{C}, \mathrm{D}$ ) and $\mathrm{B}_{10}$ (lanes E, F), anti pp 120 antibodies (lanes $\mathrm{G}, \mathrm{H}$ ) and control serum (lane I). Insulin-stimulated $\beta$ subunit (92 kDa) was immunoprecipitated by $B_{8}$ (lane $D$ ) and $B_{10}$ (lane F). Anti pp120 antibodies failed to immunoprecipitate the $105 \mathrm{kDa}$ phosphoprotein (lanes $\mathrm{G}, \mathrm{H}$ ) to brain receptor remained high and constant despite the fall in protein concentration from $500 \mu \mathrm{g} / \mathrm{ml}$ (fraction 2) to $25 \mu \mathrm{g} / \mathrm{ml}$ (fraction 9).

\section{Cross-linking of ${ }^{125}$ I-insulin to liver and brain receptors}

Crosslinking of the insulin receptor and SDS-PAGE run under reducing conditions revealed $\alpha$ subunits from both brain and liver insulin receptors (Fig. 6, lane B and F). The brain receptor $\alpha$ subunit had an apparent MW of $120 \mathrm{kDa}$ compared to $135 \mathrm{kDa}$ for liver. Unlabeled insulin $(10 \mu \mathrm{g} / \mathrm{ml})$ abolished the bands from both brain and liver (Fig. 6, lanes A and E). Neuraminidase treatment increased the electrophoretic mobility of the $\alpha$ subunit from liver (Fig. 6, lane G) but failed to affect brain $\alpha$ subunit (Fig. 6, lane C).

\section{Phosphorylation of exogenous substrates by liver and brain insulin receptors}

Insulin stimulated the receptor-induced phosphorylation of synthetic tyrosine polymers (Table 1 ). This effect was time and dose dependent (data not shown) with maximum effect at an insulin concentration of $10^{-7} \mathrm{~mol} / \mathrm{l}$. The most efficient incorporation was demonstrated using poly (Glu, Tyr), 4:1. Basal incorporation of ${ }^{32} \mathrm{P}$ was high using liver receptors. Insulin stimulation was 5-10 times basal using brain receptor and
1.5-2 times using liver receptors. No incorporation was seen using poly (Glu, Tyr), 1:1, or poly (Glu, Ala, Tyr), $1: 1: 1$. Proinsulin was about 100 times less active than porcine insulin in both tissues. Insulin stimulated phosphorylation of poly (Glu, Tyr), $4: 1$ in rat brain and liver receptors 1.7 and 5.0 times above basal respectively using similar conditions (Table 1).

\section{Autophosphorylation of $\beta$ subunit}

WGA purified liver and brain receptors demonstrated insulin stimulated autophosphorylation of the $\beta$ subunit (Figs. 7, 8). Basal incorporation of ${ }^{32} \mathrm{P}$ was high in liver receptors, and insulin stimulated autophosphorylation was less marked than with brain receptors. Anti-receptor antiserum $\left(\mathrm{B}_{8}\right)$ immunoprecipitated the $\beta$ subunit of both brain and liver. The immunoprecipitation of brain $\beta$ subunit was less using $B_{10}$ and almost absent with liver receptors. The apparent molecular weight of the $\beta$ subunits were $92 \mathrm{kDa}$ for brain and liver (Figs. 7, 8).

A phosphoprotein band of $105 \mathrm{kDa}(\mathrm{pp} 105)$ was apparent in the brain preparation only and its phosphorylation was stimulated by insulin $\left(10^{-7} \mathrm{~mol} / 1\right)$ (Fig. 7, lane $A, B)$. Anti-receptor antiserum $\left(B_{8}\right.$ and $\left.B_{10}\right)$ failed to immunoprecipitate this protein (Fig. 7, lanes D, F). In addition, anti-pp 120 antiserum was incapable of immunoprecipitating this phosphoprotein (Fig.7, lanes G-H). 


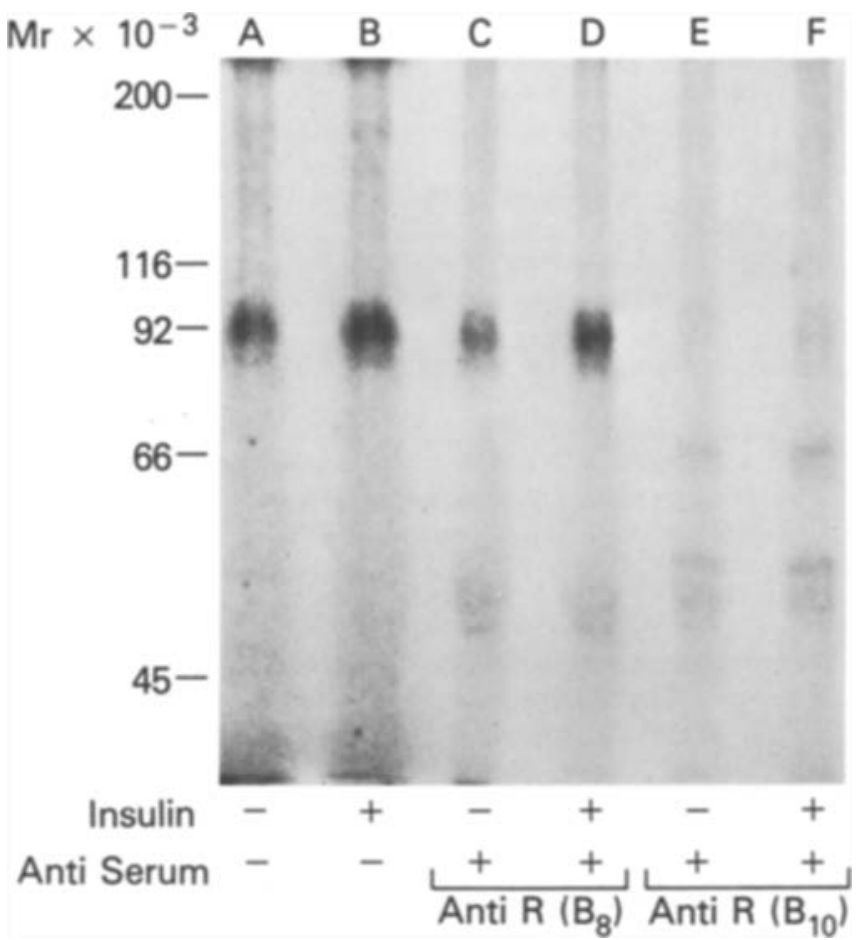

Fig. 8. Insulin-stimulated phosphorylation of liver insulin receptor. WGA purified liver insulin receptor preparations were incubated $\left(30 \mathrm{~min}, 22-24^{\circ} \mathrm{C}\right.$ ) in the absence (lane A) and presence (lane B) of $10^{-7} \mathrm{~mol} / \mathrm{I}$ insulin. The preparations were phosphorylated with [ $\left.\gamma^{32} \mathrm{P}\right]$ ATP $\left(5 \min 22-24^{\circ} \mathrm{C}\right)$. The phosphorylated preparations were immunoprecipitated with anti-receptor antibodies $B_{8}$ (lanes $C, D$ ) and $\mathrm{B}_{10}$ (lanes $\left.\mathrm{E}, \mathrm{F}\right)$. The insulin stimulated $\beta$ subunit $(92 \mathrm{kDa})$ was immunoprecipitated by $B_{8}$ (lane $D$ ). $B_{10}$ failed to immunoprecipitate the $\beta$ subunit to any significant degree

\section{Discussion}

Specific insulin receptors are present in liver and brain of the lizard Anolis carolinesis. ${ }^{125} \mathrm{I}$-insulin binding to membrane preparations from liver and brain was time, temperature and $\mathrm{pH}$ dependent in a manner characteristic of insulin receptors found in tissues from other species [7-17]. Specificity studies also demonstrated competition binding curves typical for insulin receptors with chicken insulin being 2-3 times more potent than porcine insulin, and with proinsulin about 100 times less potent. Liver crude membranes demonstrated higher specific binding per mg protein compared to brain crude membranes, whereas brain receptors demonstrated greater apparent affinity, with a further increase in apparent affinity following WGA purification [25]. In comparison, insulin binding to rat brain and liver membranes was similar. The difference between lizard brain and liver insulin binding is not readily apparent and requires further investigation.

Crosslinking of ${ }^{125}$ I-insulin to the $\alpha$-subunit of lizard liver and brain receptors revealed different apparent molecular weights on SDS-PAGE. The $\alpha$-subunit of brain receptors migrated with an apparent molecular weight of $120 \mathrm{kDa}$ whereas that for liver was $135 \mathrm{kDa}$. This difference has been previously reported in rats when comparing brain receptors to non-neural receptors [19-22]. It has been suggested that the lower molecular weight of brain $\alpha$-subunit may be due to differences in carbohydrate residues when comparing $\alpha$-subunits to non-neural tissues [19-22]. Evidence for this in lizards is two-fold. Firstly, neuraminidase, an exoglycosidase that cleaves terminal sialic acid residues, did not affect the electrophoretic mobility of lizard brain $\alpha$ subunits whereas digestion with neuraminidase decreased the apparent MW of liver $\alpha$-subunits. Similar findings have been found in the rat [21, 22]. Secondly, though both brain and liver receptors from lizard adsorbed to and were eluted from wheat germ agglutinin columns using $\mathrm{N}$-acetyl-D-glucosamine, the elution pattern of the brain receptor differed from liver. Brain insulin receptors continued to elute from the columns many fractions after the major protein peak had eluted, suggesting an unusual interaction with the column. These findings suggest that the major portion of the peak protein fraction of the WGA eluate is comprised mostly of unrelated proteins. Since glycoprotein interactions with wheat germ agglutinin are generally considered to be due to terminal sialic acid residues on the glycoprotein, the lack of effect of neuraminidase may be interpreted as indicating the absence or resistance of sialic acid residues on the brain receptor subunits [22]. Alternatively, other residues may be present on brain insulin receptors. Further studies with other lectin columns may shed more light on these differences.

Both brain and liver receptors from the lizard undergo autophosphorylation of the $\beta$-subunit. This autophosphorylation was stimulated by $10^{-7} \mathrm{~mol} / 1$ insulin. Thus, despite the difference in $\alpha$ subunits between brain and liver receptors, these studies demonstrate a coupling between insulin binding to the $\alpha$ subunit and insulin stimulated autophosphorylation of the $\beta$-subunit. Further evidence for coupling of $\alpha$ and $\beta$-subunits is the ability of brain and liver receptors to phosphorylate exogenously added tyrosine specific artificial substrates that were stimulated by insulin. The phosphorylation of these tyrosine containing substrates was most efficient for poly (Glu, Tyr), 4:1 and least efficient using the polymer (Glu, Tyr), 1:1, which is typically seen with insulin receptors [30]. Furthermore, proinsulin was 100 times less potent than porcine insulin, suggesting that the phosphorylation of the artificial substrates by both brain and liver was via the insulin receptor. The relatively higher basal phosphorylation of exogenous substrates by liver receptors compared to brain receptors may be in part related to effects by other receptors, e.g. epidermal growth factor or insulin-like growth factor receptors. This may then also account for the less marked stimulation of phosphorylation by insulin seen with liver receptors compared to brain receptors.

A prominent finding was the presence of an endogenous phosphoprotein with apparent molecular weight 
of $105 \mathrm{kDa}$ in the WGA-purified brain preparations (named pp 105). Phosphorylation of this protein was stimulated by insulin. The lack of immunoprecipitation by anti-receptor antibodies suggests that it is probably not a component of the insulin receptor. Recently, investigators have described the possible presence of endogenous substrates for phosphorylation by the insulin receptor. Rees-Jones et al. [31] demonstrated the presence of an endogenous substrate of apparent molecular weight of $120 \mathrm{kDa}$ (pp120) in liver membranes from dexamethazone treated rats, and Sadoul et al. [32] found a protein substrate ( $\mathrm{pp} 110$ ) in rat hepatocytes and rabbit adipocytes. Using the antibody directed towards pp120 [31], we failed to immunoprecipitate the lizard brain phosphoprotein ( pp 105) [31]. This phosphoprotein may, however, be similar to that described in rat hepatocytes and rabbit adipocytes [32]. Further investigation is required to substantiate its identity and function as a possible endogenous substrate for the insulin receptor. Antireceptor antibodies did, however, immunoprecipitate the $92 \mathrm{kDa} \beta$ subunit of lizard brain and liver. This suggests that lizard insulin receptors probably share some antigenic determinants with both human and rat insulin receptors [23].

In conclusion, brain and liver from lizards contain specific insulin receptors which demonstrate the presence of both $\alpha$ and $\beta$ subunits. The $\alpha$ subunit of the brain has an apparent molecular weight smaller than that of the liver. Despite these differences, coupling between the $\alpha$ and $\beta$ subunits is apparent as demonstrated by autophosphorylation of the $\beta$ subunits as well as by tyrosine specific phosphorylation of artificial substrates. Thus, the presence of functional insulin receptors in liver and brain is present in the reptile kingdom. The difference between brain and non-neural receptors is also evolutionarily highly conserved at least as early as reptiles, which are thought to have arisen more than $300,000,000$ years before mammals [33]. Although the function of insulin in the nervous system is not completely understood, the presence of specific insulin receptors in the brain strongly suggest that insulin may well have a function in the nervous system. Whether the structural differences between the brain insulin receptors and non-neural insulin receptors are related to a particular function needs to be studied.

Acknowledgements. We are grateful to Drs. J. Roth, S. Taylor, Y.Zick, N.Perrotti, J.Simon and C. Hart for helpful suggestions and V. Katz for expert secretarial assistance. We wish to acknowledge the grant for Dr. J. Shemer provided by an award to Dr. J. Roth from the Lita Annenberg Hazen fund.

\section{References}

1. Kasuga M, Hedo JA, Yamada KC, Kahn CR (1982) The structure of insulin receptor and its subunits. J Biol Chem 257: $10392-10400$

2. Ullrich A, Bell JR, Chen EY, Herrera R, Petruzzelli LM, Dull TJ, Gray A, Coussens L, Liao YC, Tsubokawa M, Mason A, See- burg PH, Grunfeld C, Rosen OM, Ramachandran J (1985) Human insulin receptor and its relationship to the tyrosine kinase family of oncogenes. Nature 313: 756 -761

3. Ebina Y, Ellis L, Jarnagin K, Edery M, Graf L, Clauser E, Ou J-H, Maslarz F, Kan YW, Goldfine ID, Roth RA, Rutter WJ (1985) The human insulin receptor cDNA: the structural basis for hormoneactivated transmembrane signalling. Cell 40:747-758

4. Van Obberghen E (1984) The insulin receptor: its structure and function. Biochem Pharmacology 33: 889-896

5. Kasuga M, Karlsson FA, Kahn CR (1982) Insulin stimulates the phosphorylation of the 95,000 dalton subunit of its own receptor. Science 215:185-187

6. Zick Y, Rees-Jones RW, Roth J (1982) Insulin-induced phosphorylation of the insulin receptor: a very early event at the target cell. Proceedings of the 11th Congress of the I.D.F. Excerpta Medica, Amsterdam Oxford Princeton, pp 161-170

7. Gavin III JR, Gorden P, Roth J, Archer A, Buell DN (1973) Characteristics of the human lymphocyte insulin receptor. $J$ Biol Chem 248: 2202-2207

8. Olefsky JM, Jen P, Reaven GM (1974) Insulin binding to isolated human adipocytes. Diabetes 23:565-571

9. Freychet P, Roth J, Neville Jr DM (1971) Insulin receptors in the liver specific binding of $\left.{ }^{125} I\right]$ insulin to the plasma membrane and its relation to insulin bioactivity. Proc Natl Acad Sci USA 68: $1833-1837$

10. Gammeltoft S, Gliemann J (1973) Binding and degradation of ${ }^{125} \mathrm{I}$ labeled insulin by isolated rat fat cells. Biochem Biophys Acta 320: $16-32$

11. Havrankova J, Roth J, Brownstein M (1979) Concentrations of insulin and of insulin receptors in the brain are independent of peripheral insulin levels: Studies of obese and streptozotocin-treated rodents. J Clin Invest 64: 636-642

12. Ginsberg BH, Kahn CR, Roth J (1977) The insulin receptor of the turkey erythrocyte: similarity to mammalian receptors. Endocrinology 100: 82-90

13. Simon J, Freychet P, Rosselin G (1977) A study of insulin binding sites in the chicken tissues. Diabetologia 13: 219-228

14. Posner BI, Kelly PA, Shin RPC, Fiesen HG (1974) Studies of insulin, growth hormone and prolactin binding: tissue distribution, species variation and characterization. Endocrinology 95: $521-531$

15. Muggeo M, Van Obberghen E, Kahn CR, Roth J, Ginsberg BH, De Meyts P, Emdin SO, Falkmer S (1979) The insulin receptor and insulin of the atlantic hagfish. Extraordinary conservation of binding specificity and negative cooperativity in the most primitive vertebrate. Diabetes 28: 175-181

16. Muggeo M, Ginsberg BH, Roth J, Neville DM, De Meyts $P$, Kahn CR (1979) The insulin receptor in vertebrates is functionally more conserved during evolution than insulin itself. Endocrinology 104: 1393-1402

17. Havrankova J, Roth J, Brownstein $M$ (1979) Insulin receptors are widely distributed in the central nervous system of the rat. Nature 272: 827-829

18. Woods SC, Lottes EC, McKay LD, Porte Jr D (1979) Chronic intracerebroventricular infusion of insulin reduces food intake and body weight of baboons. Nature 282: 503-505

19. Ciaraldi T, Robbins R, Leidy JW, Thamm P, Berhanu P (1985) Insulin receptors on cultured hypothalamic cells: functional and structural differences from receptors on peripheral target cells. Endocrinology 116: 2179-2185

20. Yip CC, Moule ML, Yeung CWT (1980) Characterization of insulin receptor subunits in brain and other tissues by photoaffinity labeling. Biochem Biophys Res Comm 96: 1671-1678

21. Heidenreich KA, Zahniser NR, Berhanu $P$, Brandenburg D, Olefsky JM (1983) Structural differences between insulin receptors in the brain and peripheral target tissues. J Biol Chem 258: $8527-8530$

22. Hendricks SA, Agardh C-D, Taylor SI, Roth J (1984) Unique features of the insulin receptor in rat brain. J Neurochem 43: 1302-1309

23. Rees-Jones R, Hendricks SA, Quarum M, Roth J (1984) The insu- 
lin receptor of rat brain is coupled to tyrosine kinase activity. $\mathrm{J}$ Biol Chem 259:3470-3474

24. Lowry OH, Rosebrough NJ, Farr AL, Randall RJ (1951) Protein measurement with the folin phenol reagent. J Biol Chem 193: 265-268

25. Hedo JA, Harrison LC, Roth J (1981) Binding of insulin receptors to lectins: evidence for common carbohydrate determinants on several membrane receptors. Biochem 20:3385-3390

26. Udenfriend S, Stein S, Bohlen P, Dairman W (1972) Fluorescamine: A reagent for assay of amino acids, peptides, proteins and primary amines in the picomole range. Science 178: 871-872

27. Harrison LC, Itin A (1980) Purification of the insulin receptor from human placenta by chromatography on immobilized wheat germ lectin and receptor antibody. J Biol Chem 255: 12066-12072

28. Taylor SI, Samuels B, Roth J, Kasuga M, Hedo JA, Gorden P, Brasel DE, Pokurqa T, Engel RR (1982) Decreased insulin binding in cultured lymphocytes from two patients with extreme insulin resistance. J Clin Endocrinol Metab 54: 919-930

29. Zick Y, Kasuga M, Kahn CR, Roth J (1983) Characterization of insulin-mediated phosphorylation of the insulin receptor in a cellfree system. J Biol Chem 256: 75-80

30. Zick Y, Grunberger G, Rees-Jones RW, Comi RJ (1985) Use of tyrosine-containing polymers to characterize the substrate specificity of insulin and other hormone-stimulated tyrosine kinases. Eur J Biochem 148: 177-182
31. Rees-Jones RW, Taylor SI (1985) An endogenous substrate for the insulin receptor-associated tyrosine kinase. J Biol Chem 260: 4461-4467

32. Sadoul JL, Peyron JF, Ballotti R, Debant A, Fehlmann M, Van Obberghen E (1985) Identification of a cellular 110,000-Da protein substrate for the insulin-receptor kinase. Biochem J 227: 887-892

33. MacLaughlin PJ, Dayhoff MD (1969) Evolution of species and proteins: a time scale. In: Dayhoff MO (ed) Atlas of protein sequence and structure, Vol 4. National Biomedical Research Foundation, S.S. Md, p39

Received: 2 December 1985

and in revised form: 28 February 1986

Dr. Derek LeRoith

Diabetes Branch, NIADDK

Building 10, Room 8S-243

National Institutes of Health

9000 Rockville Pike

Bethesda, MD 20892

USA 